\title{
PENGGUNAAN PENDEKATAN SATIR PADA IKLAN AXIS \#KENAPANGGAK
}

\author{
Indah Wenerda
}

Universitas Ahmad Dahlan; indah.wenerda@comm.uad.ac.id

\begin{abstract}
ABSTRAK
Media merupakan salah satu perangkat yang turut membentuk bagaimana praktik-praktik budaya berkembang di tengah kehidupan manusia, salah satunya melalui iklan. Hal ini dapat berlaku sebaliknya, praktik budaya yang sedang berkembang juga turut membentuk bagaimana iklan dalam hal ini diproduksi oleh para pembuat iklan. Pada Iklan Axis \#KenapaNggak yang baru saja rilis awal Bulan Mei lalu menampilkan realitas-realitas yang terjadi di tengah masyarakat masa kini, khususnya karakter anak muda zaman now. Realitas tersebut dikemas sedemikian rupa oleh pembuat iklan melalui Iklan Axis \#KenapaNggak. Tulisan ini dibuat dengan menggunakan penelitian kualitatif. Jenis penelitian yang memahami fenomena pada subjek penelitian dengan mendeskripsikannya ke dalam bentuk kata-kata dan bahasa. Dalam penelitian ini penulis akan mendeskripsikan bentuk pendekatan satir yang digunakan oleh pembuat iklan pada Iklan Axis \#KenapaNggak.Iklan Axis konsisten sejak tahun 2008 membuat iklannya dengan tidak menampilkan kekurangan provider lain sebagai competitor-nya. Melainkan menampilkan sesuatu yang masih relevan dengan fungsi atau kegunaan dari produk. Cara yang digunakan adalah dengan menggunakan pendekatan humor yang disampaikan secara satir. Visualisasi yang ditampilkan melalui gaya visual slice of life, life style, dan personality simbol, yang ketiganya kemudian dikombinasikan menjadi satu pada Iklan Axis \#KenapaNggak adalah bentuk ejekan produsen kepada khalayak masa kini sebagai pengguna super aktif internet.
\end{abstract}

Kata kunci: iklan, Axis, pendekatan, satir.

\begin{abstract}
Media is one of the tools that helped shape how cultural practices develop in the midst of human life, one of which is through advertising. This can be the opposite, developing cultural practices also contribute to how advertising in this case are produced by advertisers. In the \#KenapaNggak Axis Ad, which was just released in early May, it displays the realities that are happening in today's society, especially the character of today's young people. This reality is packaged in such a way by ad makers through Axis Ads \#KenapaNggak. This paper is made using qualitative research. This type of research understands the phenomenon in the subject of research by describing it in the form of words and language. In this study the author will describe the form of the satirical approach used by advertisers on Axis Ads \#KenapaNggak. Axis ads are consistent since 2008 making their advertisements by not displaying the shortcomings of other providers as competitors. Rather it displays something that is still relevant to the function or usefulness of the product. The method used is to use a humorous ap proach that is conveyed satire. The visualization displayed through visual slice of life, life style, and personality symbols, which were then combined into one on the Axis Ad \#KenapaNggak is a form of mockery of producers to today's audiences as super active internet users.
\end{abstract}

Keyword: advertising, Axis, approach, satire. 


\section{PENDAHULUAN}

Media merupakan salah satu perangkat yang turut membentuk bagaimana praktikpraktik budaya berkembang di tengah kehidupan manusia, salah satunya melalui iklan. Dalam hal ini iklan yang ada di media massa turut menyumbang bagaimana budaya yang kemudian akhirnya berkembang di tengah masyarakat. Yakninya melalui serangkaian proses industri budaya, dimana media massa turut andil dalam kemampuannya mengonstruksi realitas yang ada ke dalam realitas-realitas yang berwujud. Kemudian menjadi rujukan bagi penontonnya untuk diterapkan dalam kehidupan sehari-hari. Misalnya dalam sebuah iklan, menampilkan sebuah realitas seperti menunjukkan makna cantik pada wanita. Kemudian penonton wanita yang menonton iklan tersebut mencerap makna cantik dari iklan tersebut. Jika penonton wanita menerapkan sesuatu terkait praktik cantik dalam kehidupannya, dengan demikian realitas iklan yang ditampilkan telah mempengaruhi bagaimana cantik dalam pengalaman hidup satu individu.

Bila membahas mengenai iklan, iklan merupakan tayangan baik berupa audio visual ataupun hanya salah satu di antaranya yang dekat dengan keseharian kita saat ini. Hampir setiap aktivitas kita selalu dibayang-bayangi oleh iklan. Bahkan hanya sekedar membuka aplikasi pada layar smartphone kita, sepintas lalu ada tayangan berseliweran di hadapan kita. Hingga keberadaannya membuat perhatian kita sebagai user terganggu, namun demikian para pembuat iklan tetap dituntut berpikir lebih keras lagi dalam bagaimana mengangkat sebuah ide untuk kemudian diolah. Selanjutnya diproses sebagai sebuah iklan dari proses awal pembuatan hingga iklan tersebut ditayangkan. Iklan tersebut ampu menyedot perhatian kita, kemudian mampu membujuk penonton membeli produk yang diiklankan. Apalagi iklan yang ditayangkan di televisi dengan keberadaan smartphone yang hampir menyita seluruh perhatian penonton dewasa ini. Akibatnya para pembuat iklan harus bekerja keras lagi dalam mencari ide agar penonton mau memberikan perhatiannya terhadap iklan yang ditayangkan.

Dalam upaya bagaimana agar penonton dapat terbujuk membeli produk yang diiklankan, para pembuat iklan harus berpikir tentang how to say-nya. How to say adalah jalan bagaimana sebuah iklan dapat menyampaikan apa yang kemudian diiklankan (what to say) (F, 2011). Pada prinsipnya ketika membahas how to say untuk what to say adalah menyoal tentang kreatifitas iklan. Prinsip utama dalam kreatifitas iklan adalah bagaimana membuat sesuatu yang belum pernah ada, dengan upaya memilih ide-ide yang ada, menggabungkan ide-ide yang sudah ada, kemudian menghasilkan sesuatu yang baru. Dengan demikian para pembuat iklan harus memikirkan bagaimana strategi kreatif yang akan dikerjakan dalam pembuatan sebuah iklan di antara banyaknya iklan yang sudah ada saat ini. Dari penjelasan tersebut, pada tulisan ini penulis akan melakukan penelitian tentang "strategi kreatif Iklan Axis \#KenapaNggak".

\section{METODOLOGI PENELITIAN}

\section{Periklanan}

Iklan merupakan salah satu bentuk promosi yang paling dikenal dan banyak dibahas oleh orang. Hal ini berkemungkinan bahwa iklan mempunyai daya jangkauan yang luar akibat melibatkan media massa seperti TV, radio, majalah, ataupun koran. Iklan juga nenjadi instrumen promosi yang penting, apalagi bagi perusahaan yang memproduksi 
barang atau jasa yang ditujukan kepada masyarakat luas. Jika dicermati belanja iklan di Indonesia tahun 2005 silam tercatat sekitar $\mathrm{Rp} 23$ triliun rupiah. Iklan televisi mendominasi sekitar 70\% atau sekitar Rp 16 triliun dari total nilai belanja.

Pada uraian di bagian pendahuluan telah dijelaskan bagaimana iklan turut menyumbang dalam pembentukan perilaku masyarakat. Hal ini ditandai dengan realitas yang dikonstruksi sedemikian rupa dalam upaya mempromosikan barang atau jasa pada sebuah iklan. Ketika harus menggunakan iklan dalam mempromosikan barang dan jasa tersebut dituntuk kemampuan yang baik bagi pembuat iklan dalam menghasil cara yang baru saat membuat iklan tersebut.

Memahami berbagai budaya merupakan hal penting bagi pembuat iklan dalam memperluas pasar produknya. Apalagi perluasan wilayah hingga ke manca negara. Tentunya setiap negara ataupun daerah memiliki kebudayaan, tradisi, kebiasaan, dan nilai-nilai tertentu yang harus dipahami dalam proses pembuatan iklan. Yang kemudian dipertimbangkan dalam proses perencanaan dan pelaksanaan pembuatan iklan.

Jika diperhatikan kelompok atau masyarakat yang lebih kecil, subbbudaya masingmasing mempunyai kepercayaan, nilai-nilai, norma, dan pola perilaku yang berbedayang kemudian dapat dibedakan lagi berdasarkan atas umur, ras, agama, etnik, dan wilayah geografis. Subbudaya yang berbeda ras atau etnis merupakan faktor terpenting yang harus dipikirkan oleh bagian pembuatan iklan karena jumlah yang besar, pertumbuhan yang tinggi, hingga daya beli yang kuat, dan pola pembelian tertentu yang dimiliki.

Selain itu pertimbangan kelas sosial juga harus dipikirkan oleh bagian pemasaran dalam hal ini para pelaku pembuat iklan. Kelas sosial adalah pembagian masyarakat yang relatif homogen dan permanen, yang tersusun secara hierarkis dengan anggota yang menganut nilai-nilai, minat, dan perilaku yang sama. Kelas sosial diatur berdasarkan penghasilan, pekerjaan, pendidikan, dan tempat tinggal. Orang yang berasal dari kelas sosial yang berbeda akan memiliki cara berbusana, berbicara, dan preferensi rekreasi yang juga berbeda. Kelas sosial menunjukkan preferensi produk dan merek yang berbeda dalam banyak hal, seperti pakaian, perabotan rumah tangga, kegiatan waktu luang, dan lainnya. Kelas sosial menjadi patokan bagi bagian pemasaran termasuk dalam hal ini para pembuat iklan dalam merujuk kelas sosial mana yang dituju (Morissan, 2010).

\section{Strategi Kreatif}

Dalam proses menghasilkan sesuatu yang baru-diperlukan kegiatan diskusi antara pembuat iklan yaitu penulis naskah, sutradara, dan kru yang lainnya serta melibatkan klien yang memesan iklan tersebut. Dalam kegiatan diskusi tersebut tim harus memikirkan poin-poin kreatif yang biasanya dianggap sebagai bentuk terjemahan tim terhadap produk yang kemudian akan disampaikan kepada penonton. Orang-orang yang ada di dalam tim ini adalah orang-orang yang harus mempunyai daya pikir multilateral, membaca sederet buku, melakukan pengamatan terhadap perilaku manusia, kondisi sosial yang ada serta selalu tanggap dengan perkembangan teknologi.

Dalam mengupayakan agar pesan yang dibuat dapat diterima oleh penonton, maka pembuat iklan harus menentukan tema yang harus sesuai dengan target audience. Menurut Shimp (Shimp, 2003) ada beberapa faktor yang dapat dipertimbangkan untuk dijadikan strategi kreatif, yaitu : 
- Pengungkapan fakta produk atau jasa : pengungkapan informasi tentang tujuan dan keuntungan yang dapat diperoleh khalayak saat menggunakan produk atau jasa tersebut.

- Pendekatan emosional : upaya yang dilakukan dengan menyentuh perasaan penonton dengan menampilkan harapan, keinginan, suatu aspirasi, cinta, dan kasih sayang.

- Pendekatan humor : upaya yang dilakukan dengan menampilkan sesuatu yang lucu, membuat tersenyum, bahkan tertawa.

Iklan yang dibuat harus memiliki stoping power, sehingga penonton dapat menangkap pesan dari iklan dengan hanya perhatian sekejap. Lebih-lebih iklan yang ditayangkan di televisi, yang mana aspek telinga dan mata digunakan secara sekaligus oleh audien dalam melihat iklan. Porsi teks dan visual harus seimbang dalam pembuatan iklan (Agustrijanto, 2001).

Ada hal lain yang penting diketahui oleh pembuat iklan dalam menyampaikan pesan pada iklannya. Yaitu bagaimana gaya yang digunakan dalam menyampaikan pesan sehingga dapat menarik perhatian penonton. Gaya ini digunakan dalam iklan untuk memicu ingatan penonton dan pemancing untuk penonton ingat kembali dari iklan yang sudah dilihat. Secara otomatis gaya mencerminkan identitas dari merek saat diiklankan. Adapun menurut Budiman Hakim (Hakim, 2005), juga mengemukakan bahwa dalam sebuah iklan harus memiliki nilai SUPER " $A$ ", berikut :

1. Simple : tidak banyak elemen yang digunakan dalam iklan, tetapi pesan yang disampaikan dalam iklan bersifat komunikatif.

2. Unexpected: iklan harus dibuat dengan ide yang tidak terduga dan mudah diingat.

3. Persuasive : iklan yang baik dapat membujuk penonton untuk tergerak membeli produk yang diiklankan.

4. Entertaining : iklan yang baik merupakan iklan yang dapat menghibut penonton.

5. Relevant : iklan diperbolehkan melantur, tetapi tetap harus relevan dengan produk yang diiklankan.

6. Acceptable : yang terutama, penonton dapat menerima pesan yang disampaikan dalam iklan.

Berikut beberapa gaya visual menurut Russel dan Ronald (Suyanto, 2005) yang digunakan pembuat iklan dalam pembuatan iklan komersial televisi :

1. Spokesperson : teknik yang menampilkan seseorang berada di depan kamera langsung membawakan iklan kepada penonton.

2. Close ups : teknik yang menampakkan produk dari dekat agar terlihat menarik.

3. Storyline : teknik iklan yang dibuat seperti film yang sangat pendek. Iklan ditampilkan dengan jalinan cerita sekaligus dengan dramatisasinya.

4. Direct product comparation : teknik membandingkan dua produk sekaligus. Teknik ini cenderung menunjukkan kekurangan produk pesaing dan mengunggulkan produk sendiri.

5. Komedi (humor) : teknik dengan pendekatan humor, namun mengandung resiko. Sebab jika dibuat tidak hati-hati, penonton bisa sebal.

6. Customer interview : teknik dengan gaya bertanya kepada konsumen tentang suatu keadaan tertentu. 
7. Vignettes and situation : teknik yang ditunjukkan dengan sejumlah orang yang tengah menikmati sesuatu seperti menikmati hidup, dll. Biasanya digunakan dalam iklan produk minuman, rokok, permen, dll. Penggunaan musik dan liriknya digunakan dalam menambahkan kesan/suasana.

8. Menjual langsung (straight sell) : teknik menjual langsung pada informasi produk/jasa.

9. Potongan kehidupan (slice of life) : teknik yang menampikan potongan kehidupan dengan produk sebagai pemecah masalah.

10. Gaya hidup (life style) : teknik yang menekankan bahwa produk sesuai dengan gaya hidup tertentu.

11. Fantasi (fantasy) : teknik dengan menciptakan fantasi dari penggunaan produk yang diciptakan oleh pembuat iklan.

12. Suasana atau citra (mood or image) : teknik yang membangkitkan suasana/citra di sekitar produk, seperti kecantikan, cinta, ketenangan.

13. Simbol kepribadian (personality symbol) : teknik yang menciptakan suatu karakter yang menjadi personifikasi produk yang diiklankan, dapat berupa orang, binatang, atau animasi.

14. Musik (musical) : teknik yang menggunakan musik jingle, lagu terkenal, aransemen klasik, yang menunjukkan satu karakter dari produk yang diiklankan.

15. Keahlian teknis (technical expertise) : teknik yang menunjukkan keahlian, pengalaman, dan kebanggaan perusahaan dalam membuat suatu produk.

16. Bukti ilmiah (scientific evidence) : teknik dengan menyajikan bukti survei/bukti ilmiah/laboratorium dari suatu produk disukai/unggul dari yang lain. Umumnya teknik ini mengiklankan obat bebas.

17. Bukti kesaksian (testimonial evidence) : teknik yang menyampaikan pengalaman personal selama menggunakan merek dan manfaat yang diperoleh selama penggunaan. Bukti kesaksian harus berdasarkan penggunaan nyata suatu produk, untuk menghindari masalah hukum di kemudian hari.

18. Stop motion : teknik yang menampilkan rangkaian gambar berseri yang ditampilkan secara stop motion.

19. Demonstrasi (demonstration) : teknik yang menampilkan ilustrasi keunggulan dari suatu produk melalui demonstrasi.

20. Animasi (animation) : teknik iklan yang menggunakan animasi kartun. Biasanya iklan ditargetkan untuk anak-anak.

21. Dramatisasi : teknik yang menggunakan sebuah cerita pendek dengan produk/jasa sebagai bintang yang ditampilkan dengan potongan kehidupan. Terdapat penekanan peran dari produk/jasa pada cerita yang disampaikan.

22. Kombinasi (combination) : gabungan dari beberapa teknik dalam mengeksekusi iklan.

Adapun menurut Lee, Monle dan Carla (Dianti \& Herawati), konsep parodi merupakan cara yang dapat digunakan untuk menghibur dan mempengaruhi emosi penonton melalui visualisasi yang dikonstruksikan oleh para pembuat iklan melalui realitasrealitas yang ada. Pendekatan parodi pada iklan dapat menghubungkan proses logika langsung menuju ke otak pada penonton. Selain itu penggunaan pendekatan ini dirasa sangat efektif ketika seluruh perhatian penonton dapat tersita dengan kehadiran iklan tersebut (Shimp, 2003). Menurut Zinkhan (Dianti \& Herawati), pendekatan parodi juga digunakan dalam mengiklankan suatu produk dengan cara humor. Selain itu pendekatan 
ini juga disampaikan dengan meniru kebiasaan suatu masyarakat yang jalan secara satir, ironi, maupun ejekan.

Penelitian ini menggunakan jenis penelitian kualitatif. Penelitian yang bermaksud memahami fenomena yang dialami subjek penelitian dengan cara mendeskripsikan ke dalam bentuk kata-kata dan bahasa (Moleong, 2008). Dalam penelitian ini penulis akan mendeskripsikan pendekatan satir yang digunakan oleh pembuat iklan pada Iklan Axis \#KenapaNggak.

\section{HASIL DAN PEMBAHASAN}

Salah satu iklan televisi terbaru yang hadir di tengah masyarakat yang akan dibahas dalam tulisan ini adalah iklan Axis \#KenapaNggak. Jika melihat ke belakang dari iklaniklan sebelumnya, Axis sudah menggunakan konsep diferensiasi dalam mengiklankan produknya. Axis memilih cara dengan tidak menjatuhkan competitor sesama produk provider yang lain pada iklannya (Dianti \& Herawati). Menurut penelitian sebelumnya konsep kreatif yang digunakan provider Axis fokus menggunakan pendekatan parodi dalam menyampaikan pesan kepada penonton, termasuk edisi iklan \#KenapaNggak yang baru ini.

Pada iklan Axis \#KenapaNggak cerita yang ditampilkan adalah kebiasaan masyarakat saat ini yaitu sebagai pengguna aktif internet melalui smartphone. Jika merujuk hasil survei APJII tahun 2017 pengguna internet dari total populasi penduduk di Indonesia 262 juta orang, hampir sebanyak 143,26 juta jiwa merupakan pengguna aktif internet. Di antara pengguna aktif tersebut kelompok terbanyak ada pada rentang usia 19-34 tahun, sebanyak 49,52\%. Gambaran pengguna aktif inilah yang ditampilkan secara satir oleh pembuat iklan dalam iklan Axis \#KenapaNggak pada visualisasinya.

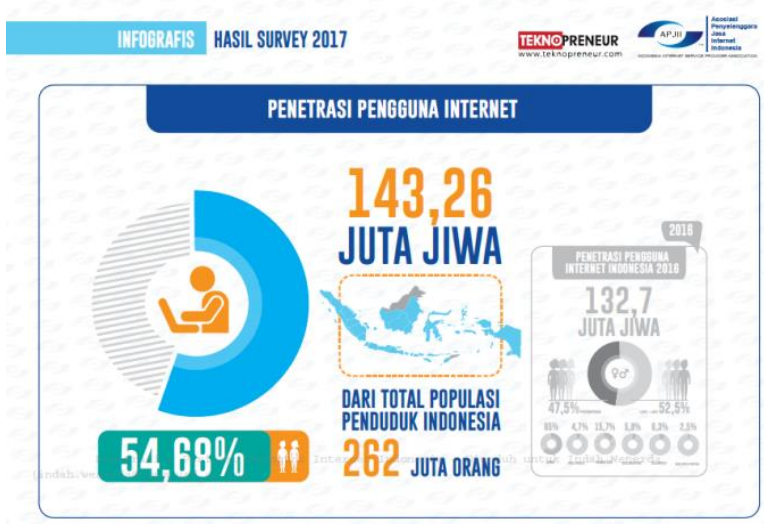

\section{Sumber: dari Hasil Suvey APJII 2017 \\ Gambar 1. Hasil Survey APJII 2017: Pengguna Internet}

Persuasi pada iklan dilakukan dengan cara mengemas suatu konsep dalam sebuah cerita. Menurut Kleppner (Dianti \& Herawati), tugas tim kreatif adalah menemukan sebuah ide untuk dibuatkan cerita yang tak terduga dan menarik dalam menggambarkan sebuah produk. Pada Iklan Axis \#KenapaNggak ide yang dibuatkan adalah sesuatu yang tak terduga, yakni menggambarkan kebiasaan masyarakat masa kini yang aktif sebagai pengguna internet. Menurut penulis ide ini dibuat sebagai bentuk stoping power yang dikemas oleh pembuat iklan, agar dapat diingat dengan mudah oleh penonton. 
Sesuai dengan yang disampaikan oleh Budiman Hakim, Iklan Axis versi \#KenapaNggak ini memenuhi nilai SUPER "A". Dari tataran simple elemen yang digunakan saat menyampaikan pesan tidak berlebihan, namun sangat komunikatif. Unexpected, iklan disampaikan dengan ide bahwa kenyataan saat ini persis divisualisasikan seperti yang ada pada iklan. Persuasive, dengan jalan pengungkapan fakta dari fungsi provider Axis sedemikian rupa pada visualisasinya, merupakan jalan yang sangat persuasif bagi khalayak untuk kemudian membeli provider ini. Entertaining, visualisasi pada iklan juga sangat menghibur khalayak, dengan visualisasi dari realitas yang ada disampaikan dengan pendekatan humor.

Relevant, realitas yang disampaikan pada iklan sangat relevan dengan keadaan saat ini juga dengan fungsi dan peran dari produk yang diiklankan. Axis sebagai provider menyediakan paket data, sementara fungsi dari provider tersebut dapat digunakan oleh masyarakat dalam mengakses internet. Akibatnya dengan ketersediaan paket data yang ditawarkan oleh provider Axis yang disampaikan melalui iklan Axis \#KenapaNggak dapat mengakomodir kebiasaan masyarakat saat ini yang telah disurvei oleh APJII sebagai pengguna internet super aktif. Hal ini sesuai dengan yang diungkapkan oleh Shimp, bahwa pembuat iklan harus dapat menentukan tema yang sesuai dengan target audience. Pada Iklan Axis \#KenapaNggak ini menggunakan pengungkapan fakta dari produk Axis, yang mana adanya pengungkapan informasi dari tujuan dan keuntungan yang dapat diperoleh khalayak saat menggunakan produk provider Axis.

Terakhir, acceptable, melalui pendekatan yang ada pesan yang disampaikan dari iklan ini dapat diterima oleh khalayak, baik dari realitas yang sesuai dengan keadaan masyarakat saat ini maupun dari fungsi produk yang diiklankan. Sebagai bentuk pengamatan, berikut visualisasi dari kebiasaan masyarakat yang ditampilkan dalam iklan Axis \#KenapaNggak :
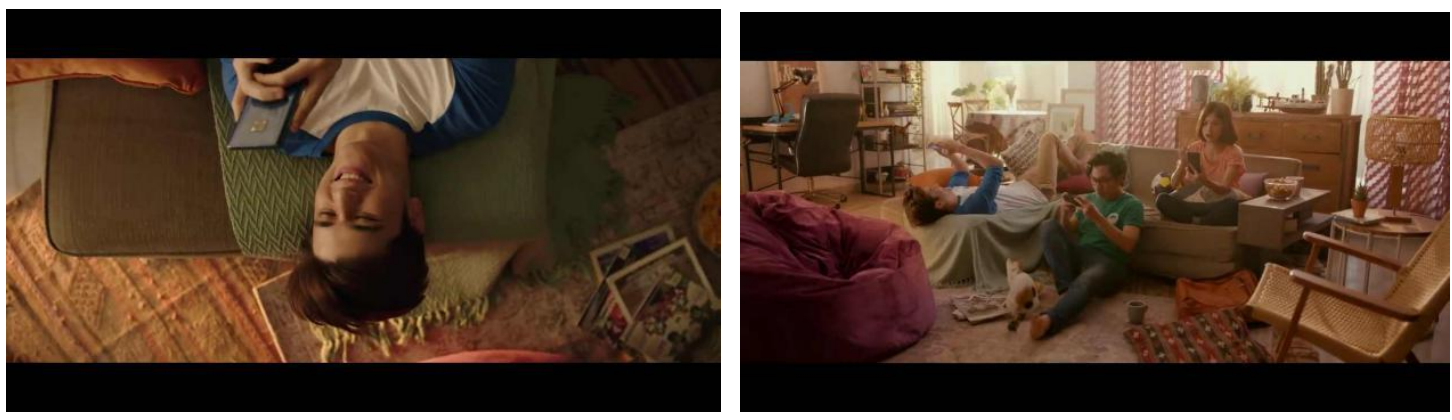

Sumber: Youtube

Gambar 2 dan 3 Potongan Iklan Axis \#KenapaNggak Narasi : "Kebebasan itu mulai dari, kenapa nggak?" 


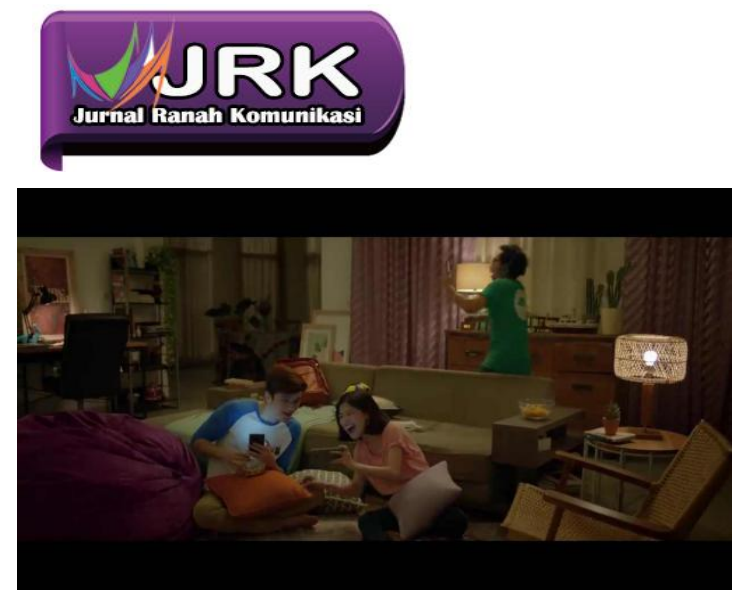

E-ISSN : 2656-4718

P-ISSN : 2302-8106

Jurnal Ranah Komunikasi (JRK)

Volume 2 Nomor 02 Tahun 2018

Sumber: Youtube

Gambar 4 dan 5 Potongan Iklan Axis \#KenapaNggak

Narasi : "Niat tidur jam 10, eh... Bablas sampai azan subuh"
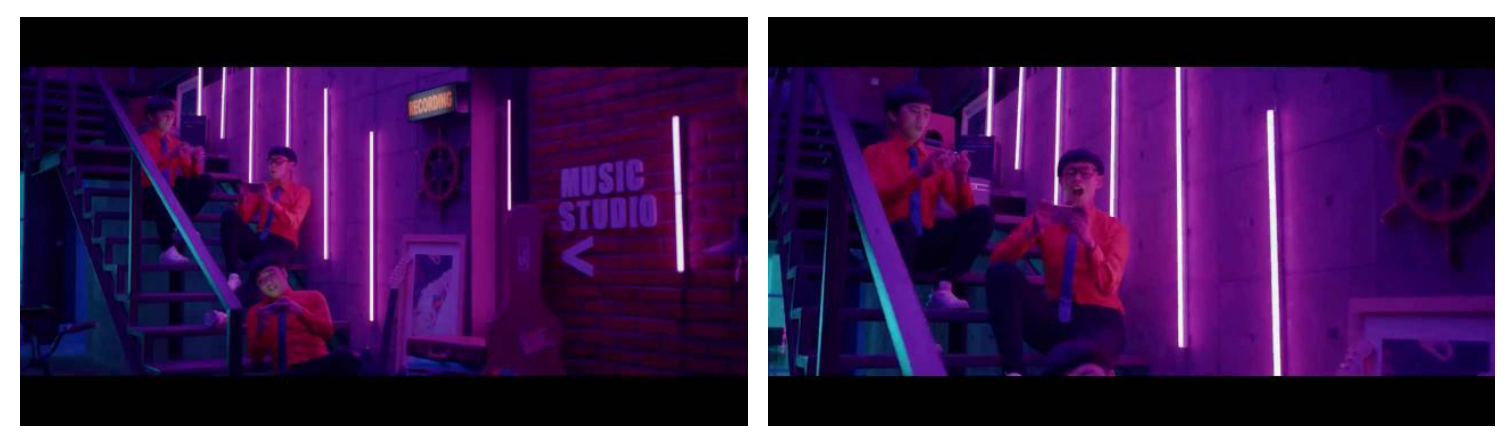

Sumber: Youtube

Gambar 6 dan 7 Potongan Iklan Axis \#KenapaNggak

Narasi : "Lagak paling snop, padahal skill nope".
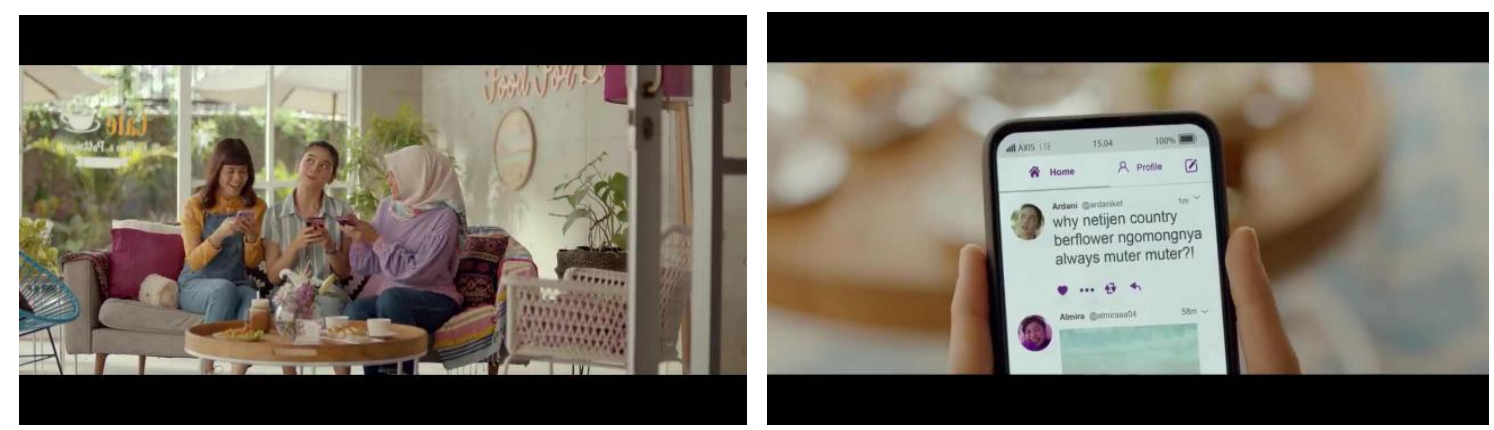

Sumber: Youtube

Gambar 8 dan 9 Potongan Iklan Axis \#KenapaNggak

Narasi : "Main twitter, biar keliatan rada pinter". 


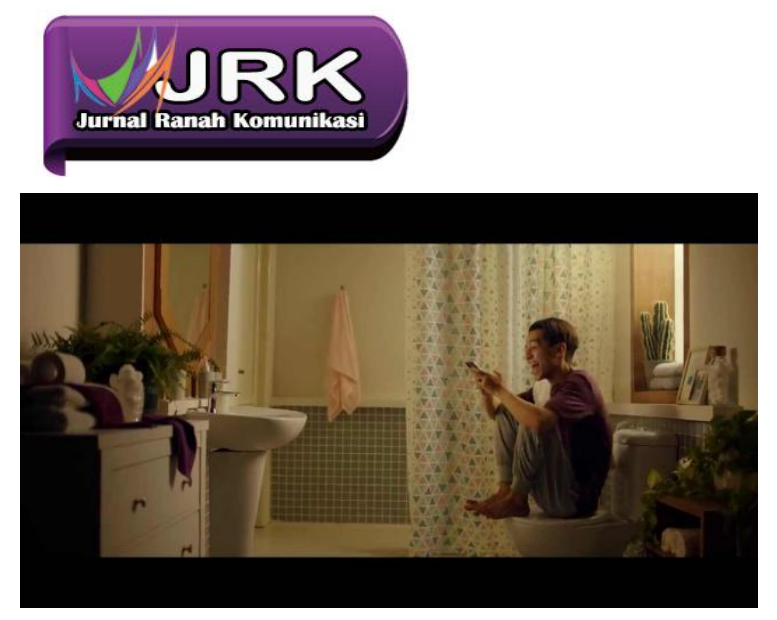

E-ISSN : 2656-4718

P-ISSN : 2302-8106

Jurnal Ranah Komunikasi (JRK)

Volume 2 Nomor 02 Tahun 2018
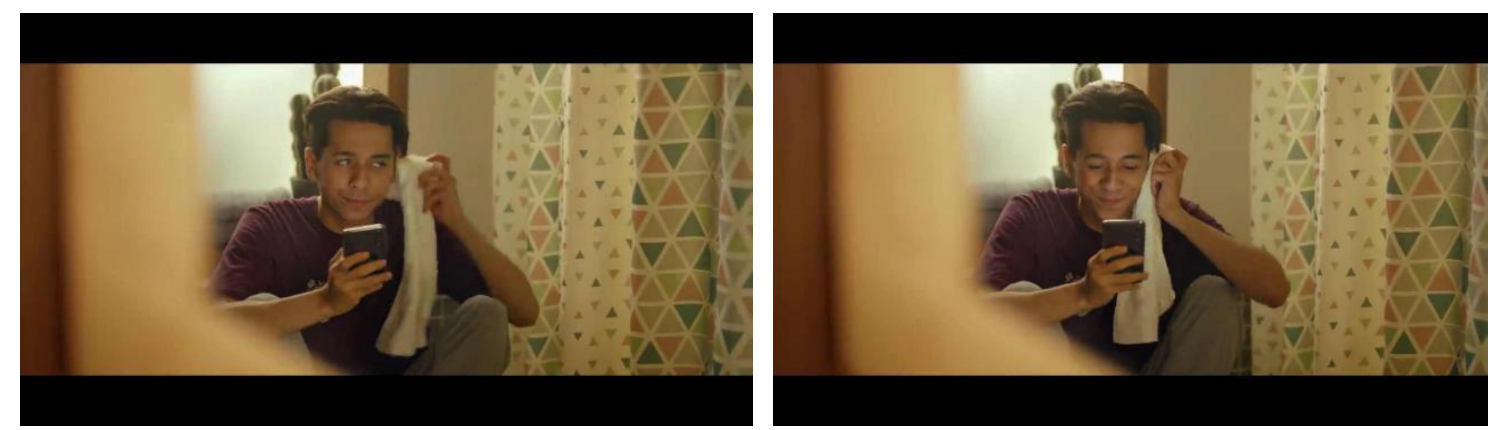

Sumber: Youtube

Gambar 10, 11, 12, dan 13 Potongan Iklan Axis \#KenapaNggak Narasi : "Duduk di toilet 50 menit, paling beneran 10 menit".

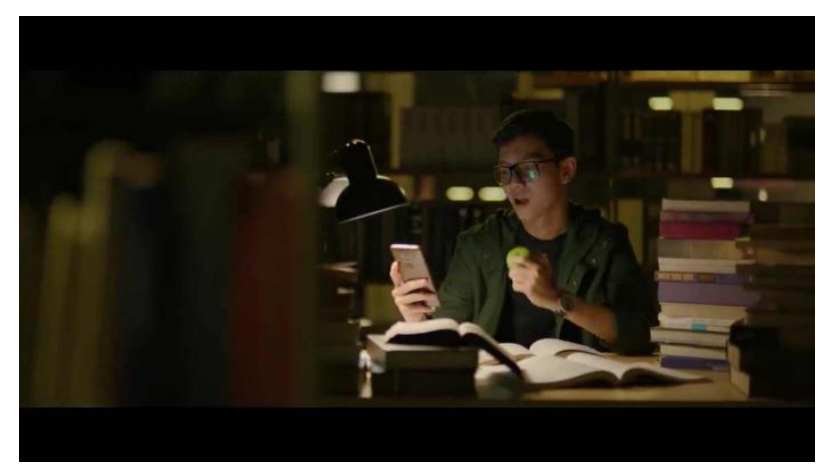

Sumber: Youtube

Gambar 14 Potongan Iklan Axis \#KenapaNggak Narasi : "Niat cari materi, malah bablas di ig".
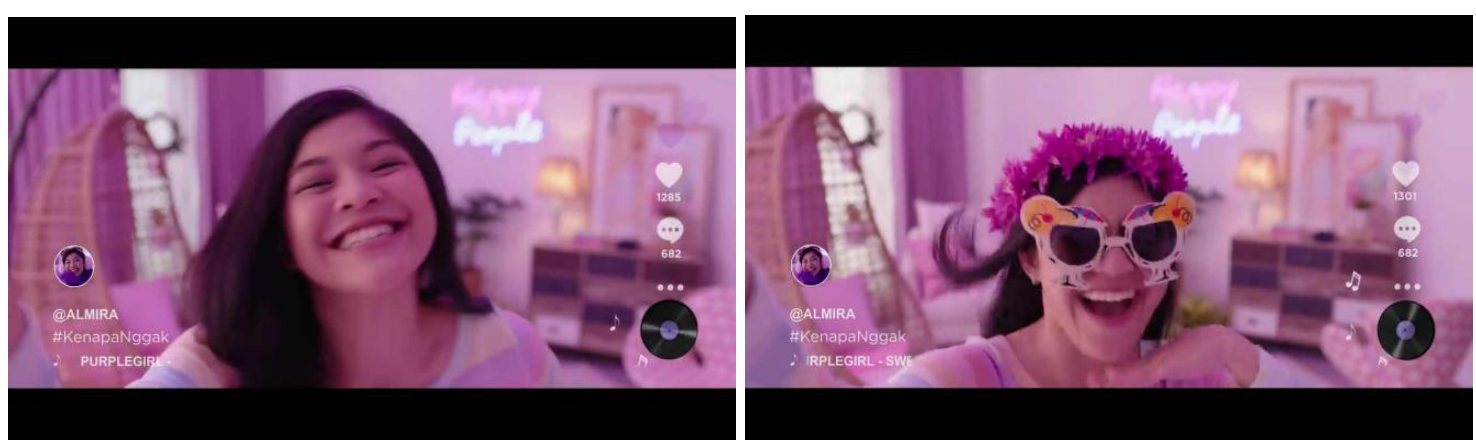


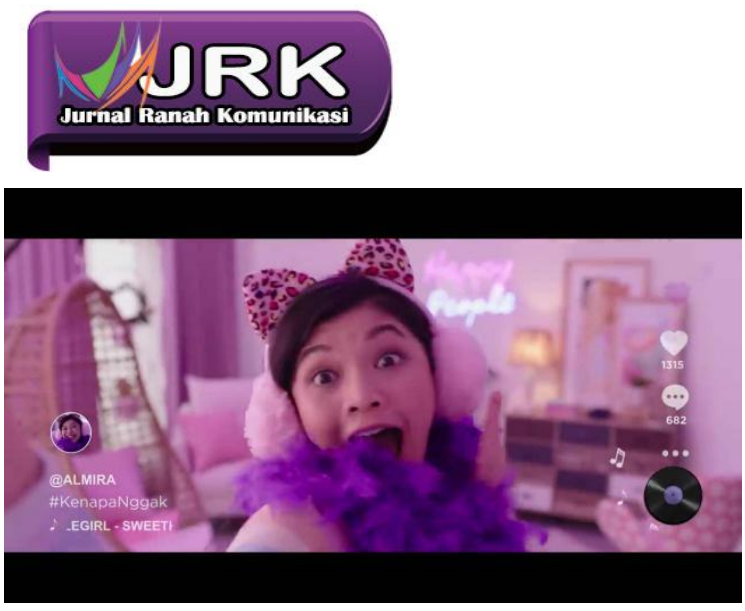

E-ISSN : 2656-4718

P-ISSN : 2302-8106

Jurnal Ranah Komunikasi (JRK)

Volume 2 Nomor 02 Tahun 2018

Sumber: Youtube

Gambar 15, 16, 17, dan 18 Potongan Iklan Axis \#KenapaNggak Narasi : “Tik tok-tik tok di dinding, diam-diam kok trending”.
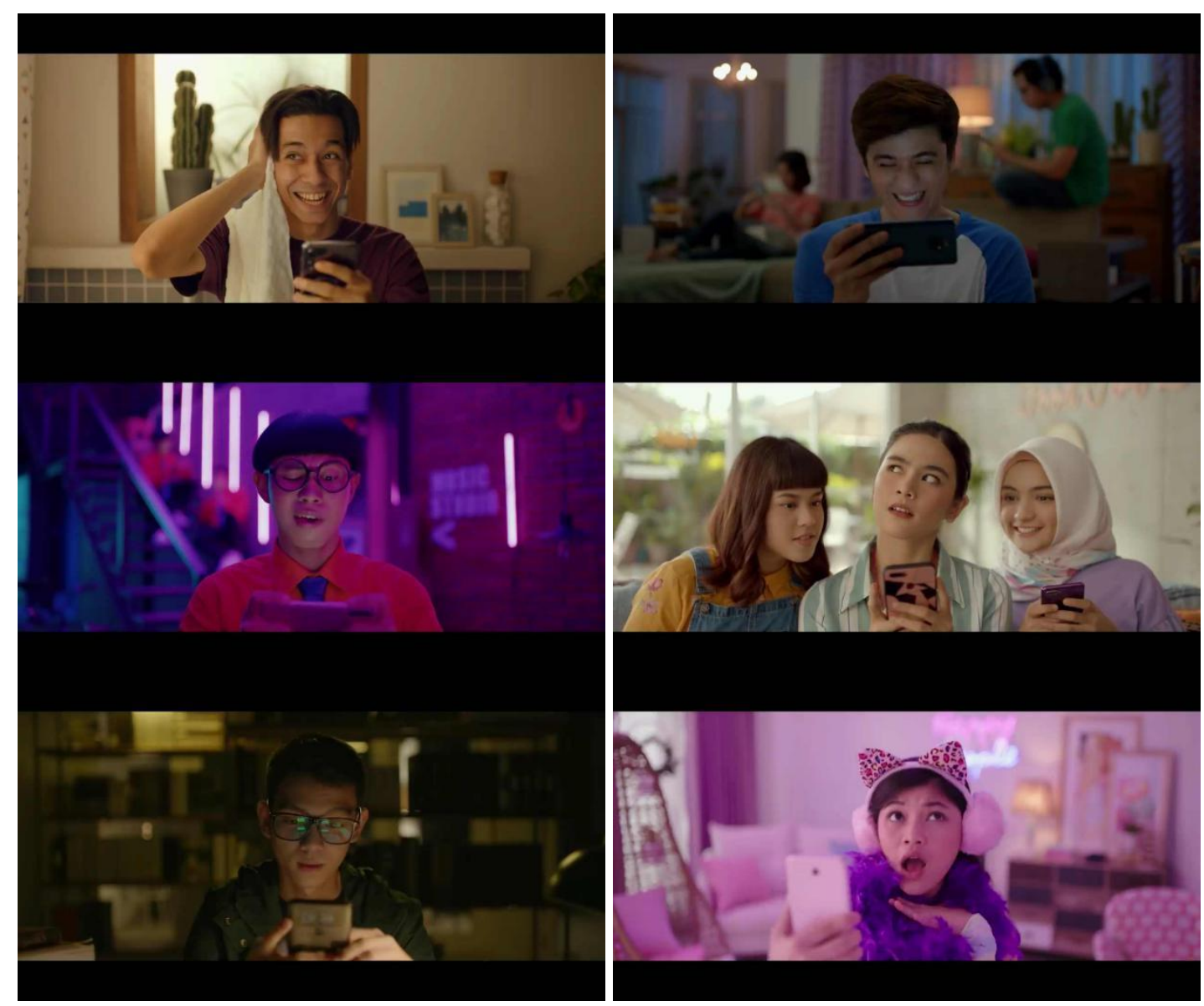

Sumber: Youtube

Gambar 19, 20, 21, 22, 23, dan 24 Potongan Iklan Axis \#KenapaNggak Narasi : "Ya jalanin aja, kenapa nggak?". 


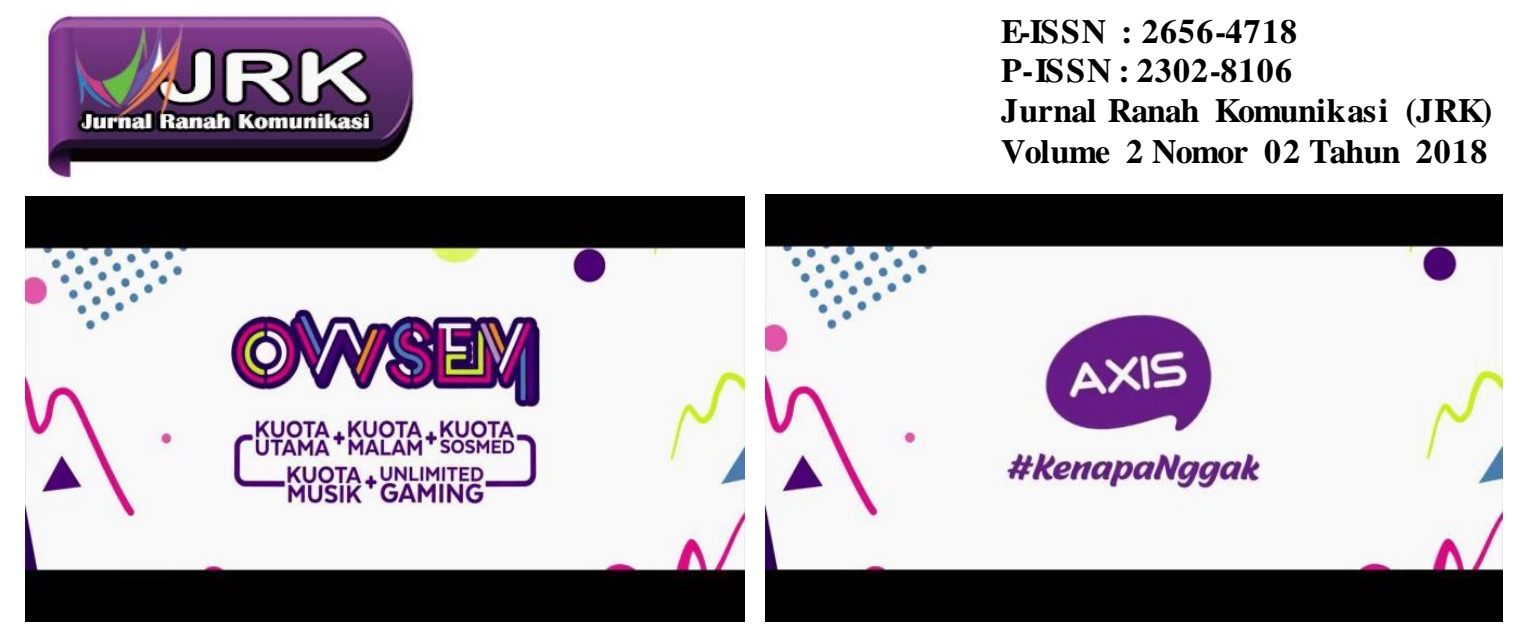

\section{Sumber: Youtube \\ Gambar 25 dan 26 Potongan Iklan Axis \#KenapaNggak \\ Narasi : “Axis, \#kenapa nggak?”.}

Berdasarkan visualisasi yang ditampilkan pada iklan Axis \#KenapaNggak di atas tampilan yang ditampilkan merupakan gambaran umum atau realitas-realitas yang terjadi di tengah masyarakat masa kini. Hal ini ditunjukkan dengan perilaku para endorser (aktor dalam iklan) ketergantungan pada smartphone mereka. Setiap aktifitas yang ditampilkan pada iklan selalu bersamaan dengan penggunaan smartphone mereka, seperti sedang bermain ke rumah teman, sedang nongkrong bersama teman ditunjukkan dua kali di tempat yang berbeda, sedang di toilet, sedang mengerjakan tugas, dan terakhir sedang membuat konten untuk aplikasi Tik-Tok. Keseluruhan aktifitas tersebut disampaikan selalu bersamaan dengan keberadaan smartphone di antara endorser yang ada. Realitas-realitas tersebut jika merujuk dari yang dikemukakan oleh Russel dan Ronald pembuat iklan menggunakan gaya visual slice of life, life style, dan personality simbol, yang ketiganya kemudian dikombinasikan dalam satu iklan ini.

Slice of life pada iklan ini ditampilkan dengan beberapa ptongan kehidupan masyarakat yang terjadi saat ini sebagai pengguna aktif internet. Dengan produk provider Axis yang dikemukakan pada iklan dapat dijadikan sebuah solusi bagi masyarakat sebagai pemenuhan internet yang tinggi. Life style ditampilkan melalui penggunaan provider Axis yang sesuai dengan gaya hidup masyarakat saat ini. Khususnya life style anak muda yang ditampilkan dengan useless, suka nongkrong, modis, multitasking, dan aktif di sosial media. Sementara personality simbol pada iklan Axis \#KenapaNggak ditampilkan dari keseluruhan bentuk iklan yang keseluruhannya adalah karakter masyarakat masa kini yaitu sebagai pengguna aktif internet. Jika lebih dikerucutkan lagi karakter yang disampaikan Iklan Axis \#KenapaNggak adalah karakter anak muda zaman now.

Jika diamati secara kausalitas antara ide cerita dengan realitas yang ada di tengah masyarakat, pada umumnya iklan menyodorkan sesuatu (yakninya produk yang diiklankan) untuk kemudian diadopsi/dikonsumsi oleh masyarakat dalam kehidupan sehari-harinya. Tetapi yang dapat penulis amati dari iklan Axis edisi \#KenapaNggak yang baru dirilis awal Mei lalu, justru menampilkan sesuatu yang saat ini sedang terjadi pada masyarakat. Pada umumnya pola yang terjadi adalah iklan dapat membentuk gaya hidup masyarakat, untuk konteks iklan ini justru yang terjadi iklan terbentuk dari gaya hidup masyarakat.

Pendekatan yang digunakan dalam iklan ini selain yang sudah disampaikan di atas yakni dengan pengungkapan fakta dari produk Axis, juga menggunakan pendekatan humor. Yakni dengan menampilkan realitas-realitas yang saat ini terjadi di tengah masyarakat, 
yang dengan realitas tersebut penonton akan tersenyum-tersenyum sendiri melihat dirinya seolah menjadi bagian dari realitas yang terjadi pada iklan tersebut. Keadaan ini sesuai dengan yang disampaikan oleh Zinkhan (Dianti \& Herawati) bahwa pendekatan humor atau pendekatan parodi digunakan dengan meniru kebiasaan masyarakat yang kemudian disampaikan secara satir, ironi, bahkan seolah seperti ejekan kepada khalayak.

\section{PENUTUP}

Pada Iklan Axis \#KenapaNggak yang baru saja rilis awal Bulan Mei lalu menampilkan gambaran umum atau realitas-realitas yang terjadi di tengah masyarakat masa kini, khususnya menampilkan karakter anak muda zaman now. Hal ini sesuai dengan penelitian sebelumnya bahwa provider Axis konsisten sejak tahun 2008 membuat iklannya dengan tidak menampilkan kekurangan provider lain sebagai competitor-nya. Melainkan menampilkan sesuatu yang masih relevan dengan fungsi atau kegunaan dari produk. Cara yang digunakan dalam menampilkan fungsi atau kegunaan dari produk Axis adalah dengan menggunakan pendekatan humor yang disampaikan secara satir. Visualisasi yang ditampilkan melalui gaya visual slice of life, life style, dan personality simbol, yang ketiganya kemudian dikombinasikan menjadi satu pada Iklan Axis \#KenapaNggak adalah bentuk ejekan produsen kepada khalayak masa kini sebagai pengguna super aktif internet.

\section{DAFTAR PUSTAKA}

Agustrijanto. (2001). Copywriting. Yogyakarta: Rosda.

Dianti, D. E., \& Herawati, L. A. (t.thn.). Implementasi Konsep Kreatif Pendekatan Paradi dalam Iklan Televisi Axis. hal. 2.

F, B. T. (2011). Strategi Kreatif dalam Membuat Iklan yang Baik dan Efektif. Surakarta. Hakim, B. (2005). Lanturan tapi Relevan, Dasar-dasar KreatifIklan. Galang Press.

Moleong, L. J. (2008). Metodologi Penelitian Kualitatif. Bandung: Rosda.

Morissan. (2010). Periklanan Komunikasi Pemasaran Terpadu. Prenada Media Group.

Shimp, T. A. (2003). Periklanan Promosi. Erlangga.

Suyanto. (2005). Strategi Perancangan Iklan Televisi Perusahaan Top Dunia. Yogyakarta. 